\title{
THE PERUVIAN EARTHQUAKE DISASTER
}

\section{Introduction}

The following is a condensation of a report in the "Peruvian Times", June 5th, 1970 which was sent to New Zealand by Miss J. Williman who was climbing in the area at the time. Fig. 1 is a map of the disaster area.

\section{The Earthquake}

The earthquake hit just before $3.30 \mathrm{p} . \mathrm{m}$. on 31st May 1970. In Lima it was felt as a strong tremor, lasting about 40 seconds. It was rated as grade 6 on the modified Mercalli Scale, which runs from 1 to 12 . Four deaths were reported from heart failure in the capital and a five-year-old girl died in Chosica, $40 \mathrm{~km}$. up the Rimac Valley from Lima, crushed by a crumbling wall.

However, damage in general was slight and quite unimportant compared with what was happening in the north.

During the next few hours radioed reports began to come in from chimbote, 250 miles away along the coast and from Huaraz, and the realization of a major disaster was evident by the early hours of the evening. though it was not until the next day, with reports coming in from the callejon de Huaylas, that the extent of it began to be known.

There was some confusion, as to where the epicenter of the shock was located. At first it was reported as being offshore of Huarmey or Chimbote, and rated as grade 8 Mercalli.

However, later reports set the epicenter in the callejon de Huaylas, with an intensity of grade 9 Mercalli.

Seismological centers abroad rated the shock at 7.7 on the international Richter scale, which is graded from 1 to 10 . One Richter is supposed to equal about 1.3 Mercalli.

On the coast the extent of the disaster was fairly quickly established, at least along the area crossed by the main Panamerican highway. Despite huge fissures in the tarmac. with sunken and broken sections, the highway has remained open all the time, though the bridge at casma has to be reached by ramps at both ends.

\section{The Consequences}

\section{A. THE MOUNTAINS : CALLEJON DE HUAYLAS}

The earthquake which hit northcentral Peru on Sunday May 31 st caused immediate and terrible loss of life and damage along the north central coast region, between roughly Pacasmayo and Huarmey. Easily the worstaffected town was chimbote where over 400 people immediately lost their lives, thousands were severely injured and tens of thousands homeless and facing dangerous shortages of water, food and medicines.

But if the situation was bad in Chimbote and along the coast, the disaster that hit the Callejon de Huaylas, the large, high, isolated and heavily populated group of mountain valleys due east of Chimbote, reached horrifying proportions.

The populated part of the callejon region slopes down, north to south from a height of about 12,000 feet a.s.1., through Huaraz, Marcara, Carhuaz, Yungay, Caraz to Huallanca, which is about 6,000 feet a.s.1. There are no reliable figures for loss of life here, as the helicopter pilots and the paratroops, coupled with aerophotographical survey, are only just now beginning to find out what has really happened. It is possible that because of the mountain formations the shock was stronger in the callejon than on the coast. But whatever damage in the mountains was caused by the shock it has been the succession of vast mud, rock and water avalanches sweeping down from the Cordillera Blanca (see fig. 3) that caused the huge loss of life.

One of the towns, Yungay, was completely wiped out. A huge avalanche of mud, rock, water and possibly ice swept down the side valley in which Yungay lay and, as Fig. 2 indicates, buried the whole town, except the cemetary hill.

In fig. 2, taken 48 hours after the earthquake hit, the little town is circled by a dotted line. What may have happened is that when the earthquake hit many of those who were not buried under the rubble of houses or seriously injured, fled for surrounding high ground, concentrating on the cemetary hill. When the avalanche swept through and around they were, though immediately safe, unable to escape in any direction. 
The same fate has almost certainly hit other smaller towns and villages in the callejon, including yet again, Ranrahirca - see fig. 3.

But the callejon de Huaylas is heavily populated all over - a majority are Quechua indians - and floods, avalanches and landslides have for a certainty hit, perhaps wiped out, many other small towns and villages. In general, though, most people in the dozens of side valleys live in widely-scattered homesteads and there is hope that most of them will have escaped what turned out to be the worst effect of the earthquake - the avalanches and floods from bursting lakes that followed the shock.

Normal conmunications and road and rail routes were completely severed by the earthquake and bad weather impeded operations by air for the first 48 hours. Even the situation in Yungay was unknown for some time because an immense cloud of dust rising, pilots reported, to over 18,000 feet blanketed the whole northxern end of the Callejon.

Apart from helicopters, of which 18 were used by the Government, paratroops were at first the only rescuers to be able to get near the whole area until late Wednesday when an emergency air-strip was made.

In common with virtually the whole of the earthquake-affected area, there was little or no drinkable water, electricity or sewerage. The risk of disease, partly from unrecovered bodies, was high.

B. THE COAST : CHIMBOTE

This fishing and industrial city of maybe 200,000 inhabitants, with its several square. miles of poor, closely packed adobe-brickwoven cane barriadas, was very much the worst hit place on the coast. Fully three quarters of the town was just shaken to the ground and still most people are living and sleeping outside the desolate heaps of rubble that remain of their homes.

There are 415 people registered as dead. Most must have died within the several seconds of the shock, crushed and suffocated by falling walls and caving-in roofs.

Further to the North, around Trujillo, practically all towns and villages were badly hit with many deaths. Inland from chimbote, in the Nepena Valley conditions were similar, and casma, south of chimbote was 95\% razed to the ground.

Some eye witness reports from Chimbote are as follows :

"When the shock hit in chimbote, bricks started flying in all directions; one child, playing with a group nearby, was struck on the head by one and killed."

"The recently finished reinforced concrete two-story convent swung to the left and then to the right and then just fell in."
Another man describes a dreadful wailing and screaming rising over the rumbling of the repeated shocks and the fantastic noise of collapsing, crashing buildings.

All the piped water was completely out of commission with pipes twisted and broken underground; the water all seeped away into the sand.

Most of the houses of two or three storys, though badly, perhaps irretrievably, damaged remain standing. One single-storey cement house, had been lifted up about four feet, and seemed at first glance intact, though at an angle. However, both the roof and the back wall had caved in. (See figures 4 and 5.)

At the town's biggest hospital, the Hospital de Obrero, which was in a bad state structurally, the injured were lying down in lines in the large central patio outside. Practically all the worst had been evacuated by ship to Lima and Callao. Near the hospital the Nurses' Home had caved in.

Emergency centers had been set up in various areas of the town, many of them associated with the locally-established parishes and missions.

The local Red Cross was very much in evidence and so were units of the corporación del Santa (which, among other things, supplies the whole region with electricity and other services). Ambulances and pick-up trucks serving as ambulances, were frequently to be seen, mostly taking injured down to be put on the ships.

In the immediate area of Chimbote the village of Coischo was, it seems, completely flattened, with many people killed by falling walls and roofs.

on the Panamerican highway going south out of Chimbote, the tarmac is badly split. One crack is 30 yards long, a yard wide and two feet deep. Two trucks were lying in the sand. They had been toppled over and off the road by the force of the shock.

Always following a disaster of this kind there are the threats of disease, and lack of food and lack of drinkable water. The water question, in a city like this in the middle of a desert, with 200,000 people to find for, was the most serious immediate problem facing Chimbote.

However, a tanker full of water was steaming for the city, as was aid from many foreign countries. 


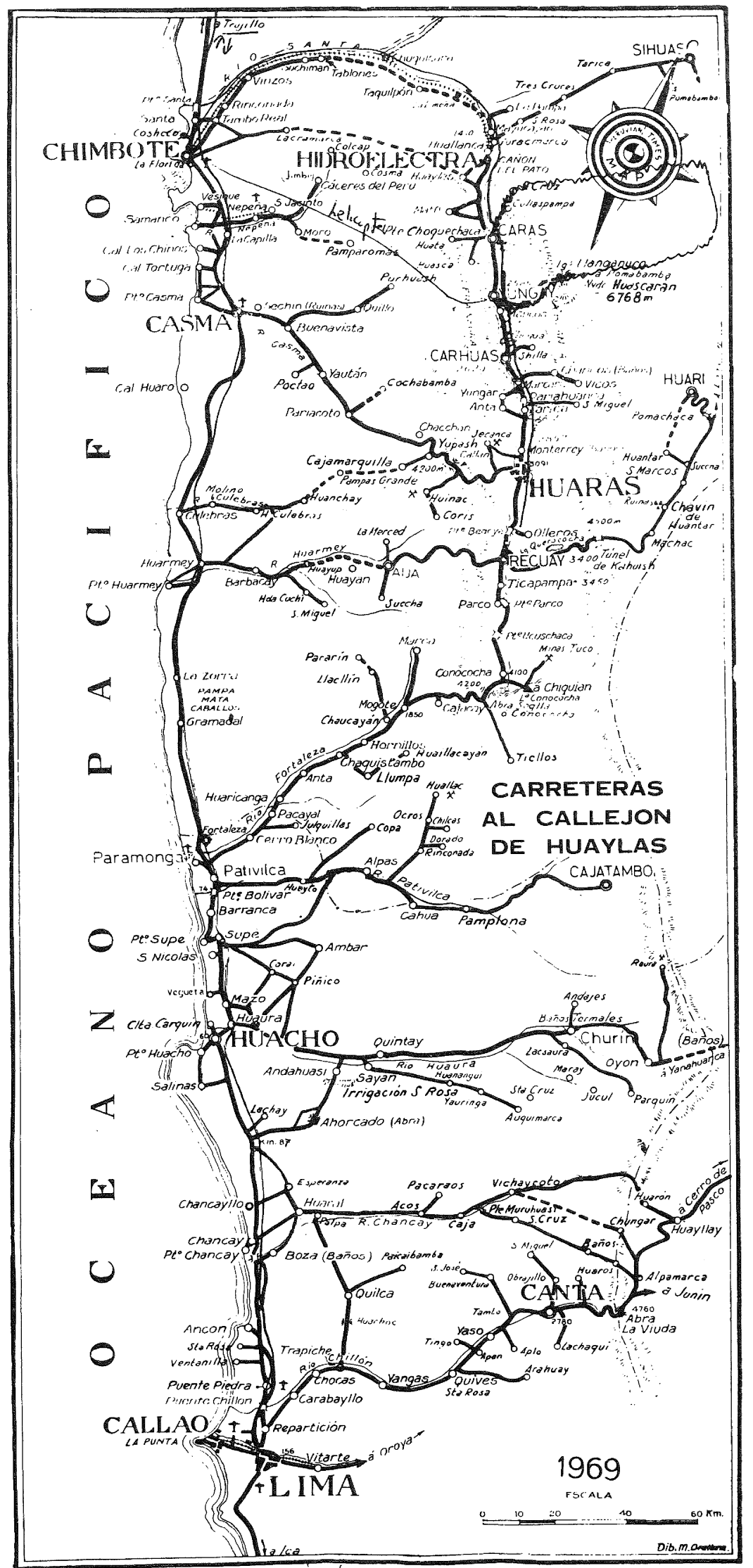

Fig. 1 


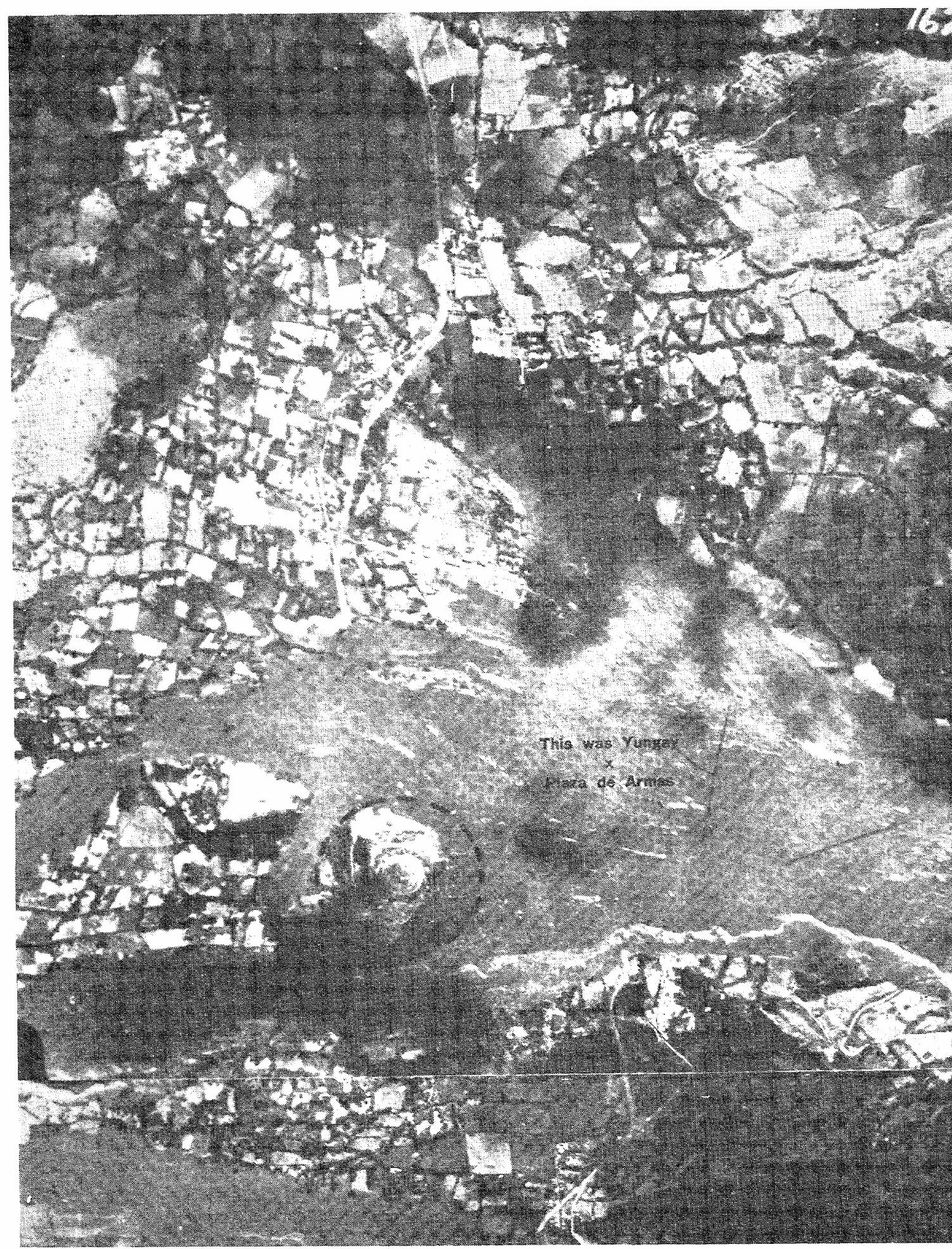

Fig. 2

Taken 48 hours after Sunday's the path of the avalanche that wiped out Yungay; at the bottom of the photo, too, can be seen the new Ranrahirca ava lanche. The dotted circle encloses the Yungay cementary hill, where helicopie pilots estimated that 2,500 peaple took refuge before the avalanche, travelling probably at 60 m.p.h., swept hrough, an unknown time after the earthquake shocks. rock and ice. The orientation of the photograph is roughly North at the top. 


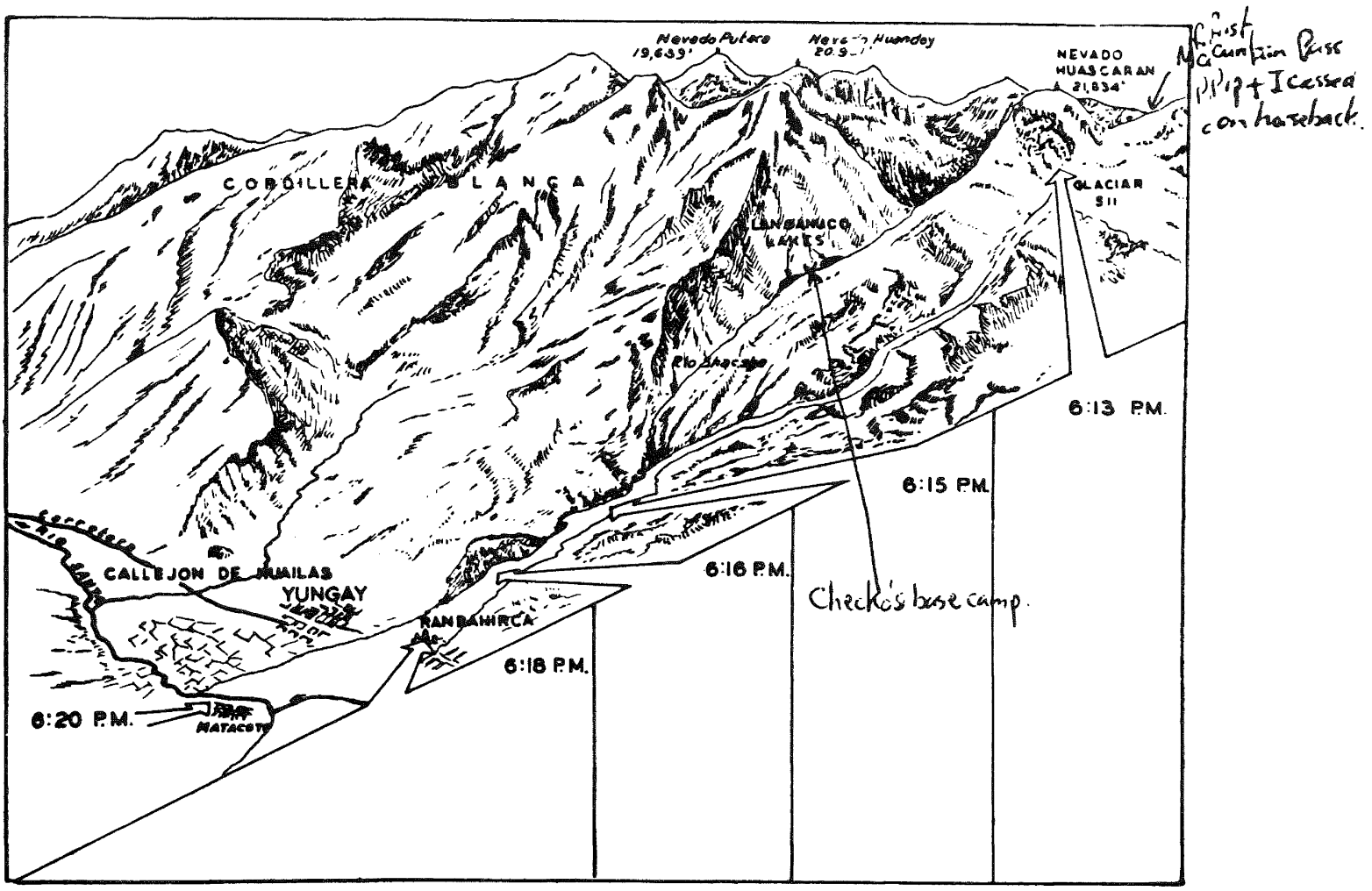

THIS diagram of the Ranrahirca avalanche disaster of January 10, 1962 clearly indicates now o similar fate has befallen the town of Yungay following the May 31 earthquake. Air Force pilots believe that the Llanganuco Lakes burst, letting loose a vast wall of water, rocks and mud down the course of the Rio Shacspa. On the cover photograph, taken by the Servicio Aerofotografico Nacional 48 hours after Sunday's earthquake, which may have had its epicenter in this area, can clearly be seen the grey wash of the remains of the avalanche. The following was the reconstructed sequence of of events at Ranrahirca, where, according to final official estimates, 3,500 people lost their lives:

6.13 p.m. Triggered by thaw, glacial cornice on the North Peak of Huascarán, weighing an estimated three million tons, falls on Glacier Ne 511 .

6.15 p.m. Carooming off canyon walls, the avalanche sweeps down on the villages and farmlands below.

6.16 p.m. The avalanche, churning with boulders, fans onto the plain. Hills banking the gorge divert the slide saving the town of Yungay.

6.18 p.m. Death sweeps down at 60 miles an hour on Ranrahirca and vicinify.

6.20 p.m. The avalanche debris falls into the Rio Santa, after a drop of $21 / 2$ miles.

The reconstruction was made by the National Geopraphic Society of Washington, from whose report this map, first published in the PERUVIAN TIMES of June 15, 1962, was adapted.

Fig. 3

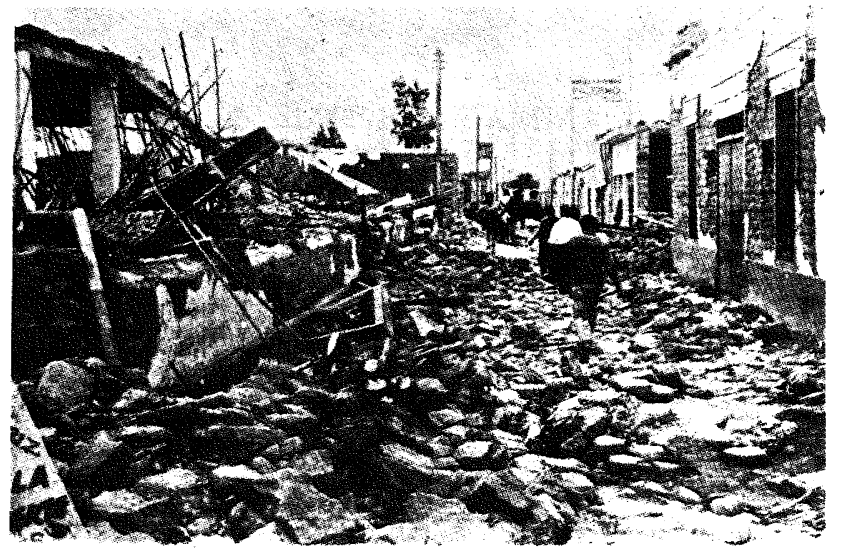

THE shock came in fast waves. A side-sireet of a coastal town

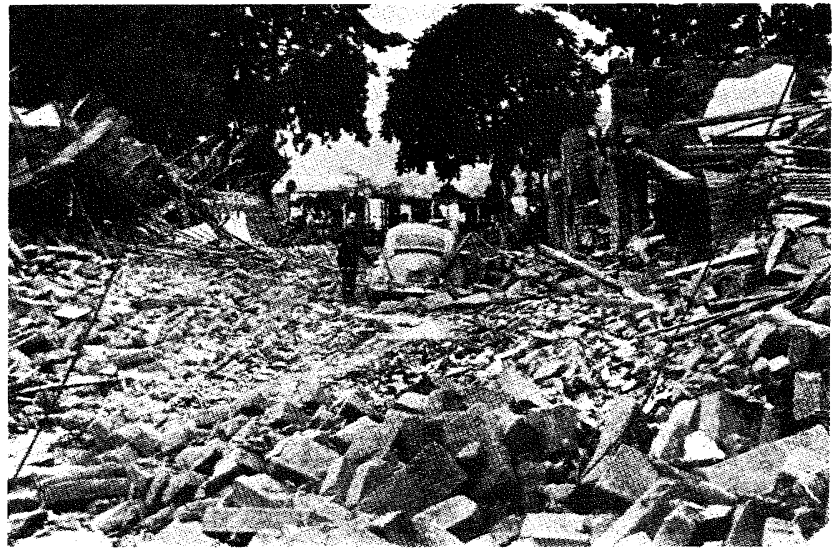

CASMA, a town on the coast was almost entirely destroyed 